\title{
FGF9 Gene Amplification
}

National Cancer Institute

\section{Source}

National Cancer Institute. FGF9 Gene Amplification. NCI Thesaurus. Code C153236.

A molecular genetic abnormality indicating the presence of multiple copies of the FGF9 gene. 